\title{
AWARENESS OF ERGONOMIC WORKING CONDITIONS AMONG EMPLOYEES
}

\author{
Iwona ŻABIŃSKA \\ Silesian University of Technology, Faculty of Organization and Management, Zabrze; Iwona.Zabinska@polsl.pl, \\ ORCID: 0000-0002-9368-4311
}

Purpose: The aim of the paper is to assess the ergonomic awareness of employees covered by the integrated ergonomic diagnosis of the working environment in terms of improving technical and psychosocial conditions in selected production and service companies.

Design/methodology/approach: The article explains the concept of ergonomic awareness and describes the degree of compliance of assessments of working conditions issued by the employees themselves with the assessments of ergonomic analyses carried out by experts. The ergonomic diagnosis was based on an in-depth interview with the employee, supported by a developed set of questions and employee observation in the workplace. The research has been carried out in 11 companies that are small and medium-sized enterprises in the Silesian Voivodeship.

Findings: The ergonomic condition of the work system is improving, but it is still not satisfactory. Conducted research revealed the need to pay attention to employees' perception of issues related to work ergonomics.

Originality/value: The results obtained are important in terms of the proper provision of working conditions.

Keywords: ergonomics, ergonomic awareness, ergonomic diagnosis, workstation.

Category of the paper: research paper.

\section{Introduction}

Research conducted in the recent years on the causes of accidents at work (Berkowska, Drzewiecka, Mrugalska, 2014; Najmiec, et al., 2013) showed that employees suffer accidents due to excessive routines or health problems and work overload, as well as incorrectly conducted training in companies. The analysis of statistical data of Statistics Poland (Główny Urząd Statystyczny, GUS) showed that $86.9 \%$ of the causes of accidents were directly or indirectly related to the organisation of work and safety culture (GUS, 2018). Among the cited reasons, the following groups were identified: employee abnormal behaviour, improper general 
organisation, lack or improper handling of a material factor, non-use of protective equipment, employee misconduct and their poor psychophysical condition. Studies conducted so far on ergonomic awareness among employees of various industries have shown that they have a moderate level of ergonomic awareness (Bartuzi, Kamińska, 2010). The problem mainly concerns improper techniques of performing various activities (positions, ways of transmission), which, in the long term, results in musculoskeletal pain (Deros, Daruis, Basir, 2015; Paul, 2012). Other research has shown that even with great knowledge of ergonomics, employees often do not use their knowledge in practice (Modi, Kuswaha, Dave, 2013; Sirajudeen, Pillai, Vali, 2013). Authors dealing with these issues have noticed that companies lack the promotion of responsibility, awareness and safe behaviour among employees (Kamińska, Tokarski, 2012; Olabode, Adesanya, 2017; Paul, 2012; Romankow, 2015).

Based on the research (Bartuzi, Kamińska, 2010), it was concluded, that even the best equipped workstation does not guarantee proper comfort and ergonomic conditions without proper knowledge and awareness of the employee in this field.

\section{The concept of ergonomic awareness}

The concept of ergonomic awareness is a typical concept on the borderline of sciences and has the nature of a cluster of concepts that should be understood as a conscious analysis of ergonomics as a phenomenon and an interesting problem area. The very concept of ergonomics is defined as a field of knowledge dealing with the adaptation of technical objects and surrounding environmental conditions to human psychophysical abilities, their needs and expectations (Górska, 2015). Ergonomics can include working and production conditions to create more efficient, better quality and safer work. It may also apply to a product that should be of high quality and safe for the user. The very concept of consciousness in the strict sense is difficult to define and refers to the feeling of experiencing specific psychological states (Encyclopedia, 2010). In general terms, it is defined as a set of beliefs or as knowledge about a given topic or the surrounding world or content of thinking. There are also presentations of consciousness in terms of individual experiences, postures, concepts, assessments, images, opinions, views etc., so there is a great variety in this area. Most often, however, consciousness is expressed in terms of knowledge or thinking.

Based on the cited literature analysis, it can be stated that, so far, no uniform definition of ergonomic awareness has been developed, which is also emphasised by other researchers in their publications (Pandve, 2016). The concept of ergonomic awareness is explained in the most detail in the works of Halina Pawlak, Agnieszka Buczaj, Anna Pecyna, Magdalena Konowałek, 2016, and Aleksandra Jasiak, 2017. According to the above studies, "ergonomic awareness is a certain state of mind, perception, based on a proper knowledge of ergonomics, which focuses 
on ensuring that conditions of external environment were adjusted to person's psychical and physical conditions" (Jasiak, 2017). In addition, the authors determined the following components of ergonomic awareness (Pawlak, Maksym, Pecyna, 2014; Pawlak, Buczaj, Pecyna, 2016):

- self-knowledge on ergonomic aspects,

- ensuring compliance with the principles of ergonomics,

- knowledge of how ergonomics is perceived,

- due diligence, care for ergonomic working conditions, in connection with the great importance of this issue.

The issue of ergonomic awareness has been particularly popular in the recent years and more and more researchers are raising this issue in their works. Some researchers deal with the analysis and assessment of ergonomic awareness of employees and employers (Jasiak, 2017; Pawlak, Maksym, Pecyna, 2014; Tariq, Zain, Muneeb, 2019; Okafor et al., 2019; Sneller, Choi, Ahn, 2018), and others by researching training methods that will allow employees to expand their knowledge of ergonomics, promoting safer work and suggesting changes in their behaviour and improvement of working conditions (Gembalska-Kwiecień, Żurakowski, 2015; Kishore, Madhwani, Nag, 2017).

\section{The purpose of the paper}

The aim of the presented research is to assess the ergonomic awareness of employees covered by the integrated ergonomic diagnosis of the working environment in terms of improving technical and psychosocial conditions in selected production and service companies.

\section{Research methodology}

As part of the project on the integrated diagnosis of an ergonomic work environment in terms of improving technical and psychosocial conditions, research has, so far, been carried out in 11 companies that are small and medium-sized enterprises in the Silesian Voivodeship. For the purposes of the project, a procedure has been developed to compare the results obtained in companies with different business profiles.

The first stage was a working meeting of ergonomics consultants with a company representative, in order to identify the research subject and discuss the principles of cooperation with regard to the specific conditions of the company and its expectations. During the meeting: 
- it was determined what kinds of jobs will be affected by the diagnosis (including the establishment of an unambiguous common nomenclature and possible deviations),

- the method of anonymising personal data was determined (enabling the compiling of data, reversing the process and directing remarks to a specific person)

- information was obtained on the expectations of the company's representative regarding the scope of the diagnosis.

The second stage was an ergonomic diagnosis based on an in-depth interview with the employee, supported by a developed set of questions and employee observation (in the workplace) including, among others:

- work process and its organisation,

- psychological and physical burdens,

- environmental load,

- work space,

- position at work,

- monotony of work,

- the pace of work,

- organisation of work in time and space,

- technical solutions affecting the environment.

The third stage was the preparation of the report. The report consisted of several permanent elements:

- collective and appropriately aggregated documentation of the research carried out (using the research tools described above),

- assessment of the current state of each examined workstation and employee,

- a document containing recommendations in the area of ergonomics for each position.

Due to the company's expectations regarding the scope of the diagnosis, the method of dividing the research documentation and the description of the recommendations was consulted with a representative of the company.

The final stage of the research was to provide the owner of the company with recommendations on the ergonomics of work of each diagnosed employee. The recommendations were consulted with the employer, so that the scope of ergonomic adjustments recommended in the report could be a real help in achieving an increase in the efficiency and quality of working conditions.

As part of the project described above, an additional result was the analysis of employees' awareness of working conditions related to ergonomics and a collection of analyses and remarks on the theory and practice of workstation organisation. In order to promote work ergonomics, selected research results have been presented in several publications (Kuboszek et al., 2018; Żabińska, Kuboszek, 2018). 


\subsection{Research sample}

The diagnosis included 130 employees forming a diverse group in terms of employment in the industry, position held, seniority and gender. There were 61 women and 69 men among the employees. The most numerous group among the diagnosed employees were people between the ages of 40 and 49 (Table 1).

\section{Table 1.}

Age structure of employment of diagnosed employees

\begin{tabular}{|c|c|c|c|c|c|}
\hline \multirow[t]{2}{*}{ Gender } & \multicolumn{4}{|c|}{ Age range } & \multirow[t]{2}{*}{ Total } \\
\hline & $40-49$ & $15-29$ & 30 - 39 & 50 and over & \\
\hline Females & 16 & 20 & 12 & 13 & 61 \\
\hline Males & 27 & 7 & 19 & 16 & 69 \\
\hline Total & 43 & 27 & 31 & 29 & 130 \\
\hline
\end{tabular}

Own study.

The structure of the sample according to education is contained in Table 5.

There were 62 office workers and 60 physical workers. Eight people performed both office and physical work. Employees were employed in companies operating in the following areas:

- production of metal joinery elements,

- production of other concrete, plaster and cement products,

- repair and maintenance of machines,

- general construction works in engineering facilities, not classified elsewhere,

- construction works associated with erecting residential and non-residential buildings,

- accounting and bookkeeping activities; tax consultancy,

- security services,

- retail sale of groceries,

- hairdressing and other cosmetic treatments,

- publishing of magazines and other periodicals.

\subsection{Tools}

The employee interview was conducted using a proprietary survey questionnaire consisting of 14 closed questions and one open question, which concerned the scope of responsibilities at the work position occupied by the employee. Eleven questions referred to the psychophysical conditions of the work performed. As part of the last question, the employee was to indicate body parts, in which they feel pain and determine its frequency and strength.

Tools were chosen to conduct the research, which allowed for a relatively quick and accurate assessment of the ergonomic situation in the analysed work environment. The following factors influenced the choice of methods: 
- short time, during which observations could be made in relation to a single workstation,

- the existence of a uniform and repeatable form for all groups and positions,

- high unambiguity of the obtained observation results (elimination of the observer's subjective assessments),

- comparability in time and space.

The tests were carried out using tools, such as the Control Ergonomic Test (CET II) and the Dortmund List (ESAC - Ergonomics System Analysis Check-list).

To analyse the situation at the workplace, the 3D SSPP (3D Static Strength Prediction Program) application was used, which uses a simplified model of the work environment and the relationships of forces and moments occurring in the musculoskeletal system for a specific human population (3D SSPP, 2018).

\section{Results}

The results of the research are presented in three parts. The first part presents the answers given by the respondents during the interview. The second part presents the results of a comparison of employees' opinions on their working conditions with the state confirmed by experts in the DL-based analysis. The last part includes a comparison of the results obtained during the analysis of the load on the musculoskeletal system, carried out in the 3D SSPP programme, to the complaints declared by employees.

\subsection{Analysis based on the survey questionnaire}

The employees were interviewed using a survey questionnaire. Respondents were to answer, among others, the following questions:

- Were ergonomic training sessions held at work?

- Would you like to gain/expand knowledge on ergonomics in your job (e.g. correct posture at work, energy output assessment, proper work organisation)?

When asking a question about training, the interviewer asked the employee to explain the concept of ergonomics. In the event that the respondent could not answer or defined the concept incorrectly, the expert explained its correct definition. Out of 130 respondents, as many as 85 people claimed that they did not participate in training on ergonomics. In particular, this opinion was declared by persons performing office work. About $33 \%$ of people doing physical work said that some issues related to work ergonomics were raised during occupational safety and health (OSH) training (Table 2). 
Table 2.

Structure of answers of surveyed employees. Own study

\begin{tabular}{|l|l|l|c|l|}
\hline \multirow{2}{*}{ Kind of work } & \multicolumn{2}{|c|}{ Were ergonomic training sessions held at work? } & \multirow{2}{*}{ T\%otal } \\
\cline { 2 - 5 } & No & Yes total] & I don't know & \\
\hline office work & $36.15 \%$ & $6.15 \%$ & $5.38 \%$ & $47.9 \%$ \\
\hline physical work & $23.85 \%$ & $15.38 \%$ & $6.92 \%$ & $46.15 \%$ \\
\hline physical work and office work & $5.38 \%$ & $0 \%$ & $0.77 \%$ & $6.15 \%$ \\
\hline Overall & $65.38 \%$ & $21.54 \%$ & $13.08 \%$ & $65.38 \%$ \\
\hline
\end{tabular}

Own study.

All employees employed at the construction site stated that, as part of the OSH training, knowledge about the correct posture at work was provided, and in addition, during various activities, the supervisor drew attention to their incorrect posture and the wrong way of carrying loads, while giving instructions on how to do it in a way that is least harmful to the musculoskeletal system.

From the answers given by the surveyed employees, it appears that 90 people would like to acquire or expand their knowledge about ergonomics, and 10 did not have an opinion on this topic. In contrast, 30 employees felt that they did not need to expand their knowledge in this area. The most numerous group, among employees who did not want to acquire or expand their knowledge about ergonomics, were people with higher education (Table 3 ).

Table 3.

Structure of answers on the desire to acquire knowledge on ergonomics

\begin{tabular}{|c|c|c|c|c|}
\hline \multirow[t]{2}{*}{ Kind of work } & \multicolumn{3}{|c|}{$\begin{array}{c}\text { Would you like to acquire or expand knowledge about } \\
\text { ergonomics in your job? } \\
{[\% \text { of total] }}\end{array}$} & \multirow[t]{2}{*}{$\begin{array}{l}\text { Total } \\
{[\% \text { of total }]}\end{array}$} \\
\hline & Yes & No & I have no opinion & \\
\hline Office work & $33.08 \%$ & $11.54 \%$ & $3.08 \%$ & $47.69 \%$ \\
\hline Physical work & $31.54 \%$ & $10.00 \%$ & $4.62 \%$ & $46.15 \%$ \\
\hline Physical work/office work & $4.62 \%$ & $1.54 \%$ & $0 \%$ & $6.15 \%$ \\
\hline Total & $69.23 \%$ & $23.08 \%$ & $7.69 \%$ & $100 \%$ \\
\hline
\end{tabular}

Own study.

$60 \%$ of the surveyed employees thought that their work was stressful. In addition, $43.8 \%$ said that they felt discomfort due to the climate conditions of the work environment. Employees also declared discomfort in the organisation of work (23.8\%) and adverse psychological climate (21\%) (Table 4). In view of the above, it is surprising that only 7 people reported the need for improvement of working conditions, including the replacement of their tasks with the operation of machines. 
Table 4.

Structure of answers on work organisation, working environment climate conditions and psychological climate at work

\begin{tabular}{|l|r|r|}
\hline Does the organisation of work (pace, breaks etc.) affect your feelings of comfort/discomfort at work? \\
\hline & Number & Percentage \\
\hline discomfort & 31 & 23.84615 \\
\hline no impact & 10 & 7.69231 \\
\hline comfort & 89 & 68.46154 \\
\hline
\end{tabular}

What impact do the climate conditions of the working environment have on your feelings of comfort / discomfort at work?

\begin{tabular}{|c|c|c|}
\hline & Number & Percentage \\
\hline discomfort & 57 & 43.84615 \\
\hline comfort & 55 & 42.30769 \\
\hline no impact & 18 & 13.84615 \\
\hline \multicolumn{3}{|c|}{ What is the impact of the psychological climate at work? } \\
\hline & Number & Percentage \\
\hline no impact & 25 & 19.23077 \\
\hline favourable & 77 & 59.23077 \\
\hline unfavourable & 28 & 21.53846 \\
\hline
\end{tabular}

Own study.

Experts pointed out, that the vast majority of employees, especially physical ones with basic and vocational education, showed fear of introducing any conveniences in the form of automation of their tasks, for fear of losing their jobs.

\subsection{Opinion of employees about working conditions and their actual state}

The next part presents the results of a comparison of employees' opinions on their working conditions with the state confirmed by experts in the DL-based analysis.

It should be emphasised that $76 \%$ of employees have properly organised work, due to physical and psychological burdens, as well as in terms of pace of work and breaks. $90 \%$ of the respondents were able to accurately assess the environmental burden and indicate potential sources of psychological and physical threat. Research has shown, however, that employees do not see workplace restrictions resulting from somatic relationships. Therefore, their opinion on the equipment of the workstation differs from the assessment of experts on this subject. Research has revealed a number of situations, in which work differed from the recommendations and guidelines for the ergonomics of working with a screen monitor. Workplaces with screen monitors constituted a small group in this study. There were a total of 75 workstations, including 55 equipped with desktops and 20 with laptops. During the diagnosis, the impact of computer equipment on the arrangement of the workstation was noticed. The relationship between the way the monitor is connected to the computer and the relationship between the arrangement of the workstation and the nature of the work has emerged. As a result, three types of computer workplaces have been distinguished:

- stationary with a separate monitor,

- stationary with a laptop,

- mobile with a laptop. 
In all the cases analysed, certain weaknesses were identified in the area of ergonomic design principles for the workstation. In most cases it was recommended to introduce changes consisting in:

- using a monitor stand to adjust its edge to the eye height,

- moving the monitor towards the employee to the recommended distance of 50-70 cm and ensuring its position directly in front of the employee,

- providing a chair with a higher backrest and armrests that allow height adjustment,

- raising the armrests to the level of the table top,

- equipping the workstation with a foot support.

\subsection{Analysis based on the 3D SSPP application}

As part of the diagnosis, the experts watched each employee for 8 hours and took pictures of positions taken during work. Then, in accordance with the observations made in the workplace, as well as the interview with the employee, the level of physical load in relation to the method of work was determined. Selected body positions were analysed in 3D SSPP programme (Figure 1).

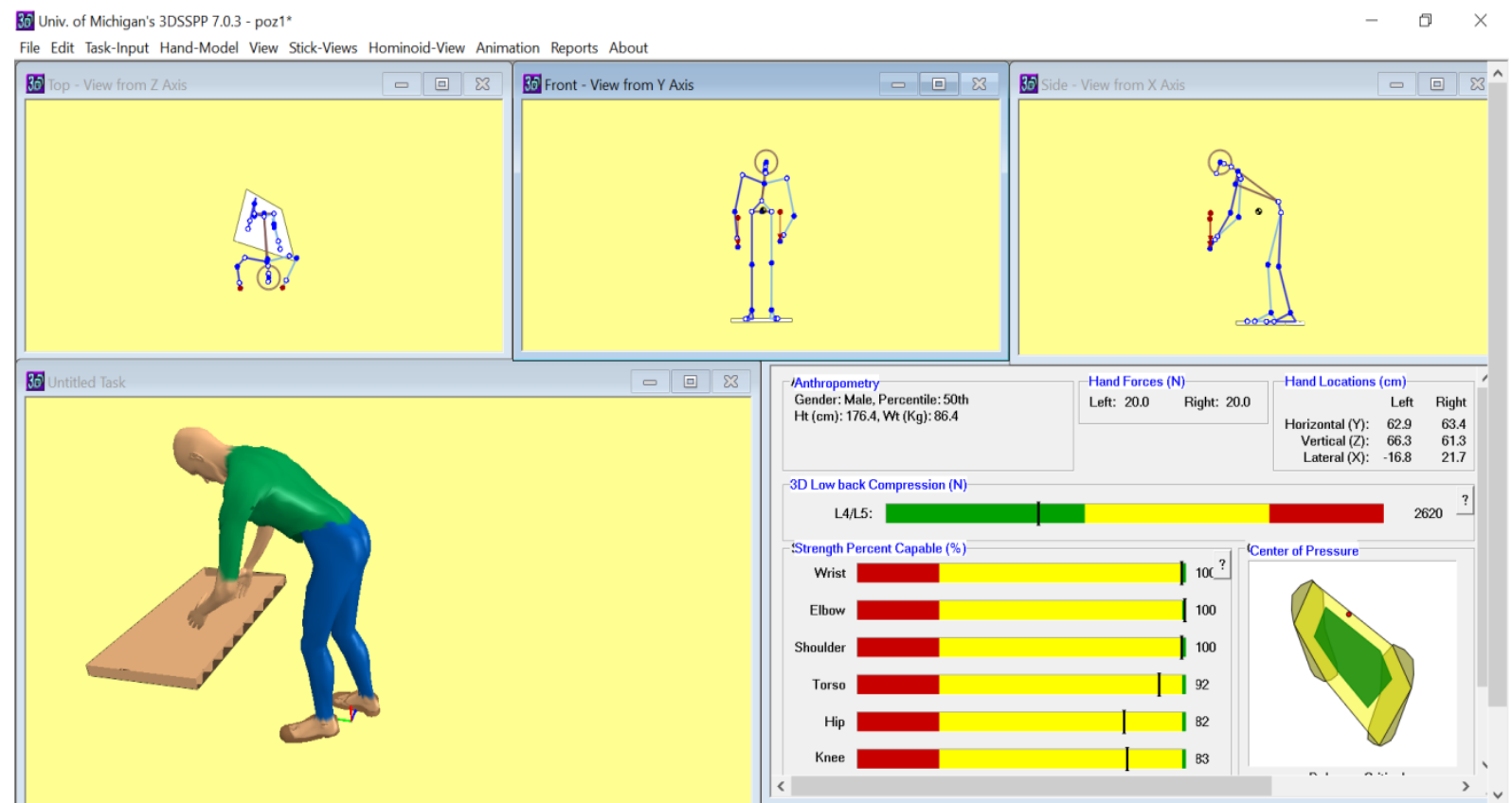

Figure 1. Graphic windows of the 3D SSPP programme (3D SSPP 2018).

After considering the programme limitations, resulting from the equations used, it was possible to determine to which musculoskeletal loads the worker was exposed. Less than $20 \%$ of respondents did not mention any complaints. From among those who indicated health problems, as much as $78 \%$ of employees complained of ailments that were also identified as part of the 3D SSPP analysis. In addition, experts noticed discrepancies between employees' perception of workload occurrences, the description of positions taken during work, and the actual form and frequency of occurring loads and positions adopted. The wrong body 
position was most often taken by office workers at work. The problem concerned even the most basic rules of using computer equipment at the workplace.

\section{Discussion}

Based on the level of awareness observed, it can be concluded that employees tend to perform their tasks routinely and neglect difficult working conditions. The analysis showed no relationship between seniority, age and kind of work performed and the level of ergonomic awareness. However, it was observed that the group that was the most negative towards training related to work ergonomics are people with higher education (Table 5). It should be emphasised, that the level of knowledge about the ergonomic workplace declared by these employees was not reflected in practice.

Table 5.

Willingness to learn about the ergonomics of the surveyed employees

\begin{tabular}{|c|c|c|c|c|}
\hline \multirow{2}{*}{ Education } & \multicolumn{3}{|c|}{$\begin{array}{l}\text { Would you like to acquire or expand knowledge about ergonomics } \\
\text { in your job? [\% of total] }\end{array}$} & \multirow{2}{*}{ Total } \\
\hline & Yes & No & $\begin{array}{c}\text { I have no } \\
\text { opinion }\end{array}$ & \\
\hline technical secondary & $5.38 \%$ & $0.77 \%$ & $0.00 \%$ & $6.15 \%$ \\
\hline secondary & $15.38 \%$ & $3.08 \%$ & $2.31 \%$ & $20.77 \%$ \\
\hline vocational & $21.54 \%$ & $5.38 \%$ & $0.77 \%$ & $27.69 \%$ \\
\hline higher & $20.00 \%$ & $10.00 \%$ & $1.54 \%$ & $31.54 \%$ \\
\hline post-secondary & $1.54 \%$ & $0.00 \%$ & $0.00 \%$ & $1.54 \%$ \\
\hline primary & $0.77 \%$ & $0.77 \%$ & $0.00 \%$ & $1.54 \%$ \\
\hline upper secondary & $4.62 \%$ & $3.08 \%$ & $3.08 \%$ & $10.77 \%$ \\
\hline Total & $69.23 \%$ & $23.08 \%$ & $7.69 \%$ & $100 \%$ \\
\hline
\end{tabular}

Own study.

A detailed analysis of the level of awareness of people who were strongly opposed to expanding their knowledge of ergonomics showed, that the degree of compliance of assessments of working conditions issued by the employees themselves with the assessments of ergonomic analyses (especially 3D SSPP computer analysis) carried out by experts varied significantly. 78 workstations showed weaknesses in the principles of ergonomic workstation design. In most cases, the equipment of the workstation did not allow for a proper body position at work. Most employees who work in a sitting position (office worker, watchmaker, driver etc.) have been diagnosed with risks related to the load on the upper part of the spine, elbow and wrist. It is true that their work was not associated with high physical load, but prolonged stay in the adopted positions could be tiring and even cause bodily disorders. It should be emphasised, that more than half of the diagnosed employees did not notice their faults in posture. It is surprising that employees in heavy physical work (concrete workers, steel fixers, builders, locksmiths), who were doing the work in the most ergonomic way possible, had more 
awareness in this respect. In their case, the lack of ergonomics was a result of the conditions created by the employer, who did not always provide ergonomic tools, machinery and equipment, as well as proper working conditions resulting from the work environment, primarily including noise. Among the discussed group of physical workers, pain in the lower part of the spine, wrist and hands was the most common. The analysis made with the help of the 3D SSPP programme confirmed, that these are the most common threats associated with high physical load performed by employees employed in construction works. In the case of retailers, hairdressers and beauticians, first of all, the risks associated with strain to the knees, lower leg and upper and lower parts of the spine were diagnosed.

Experts stated that only $10 \%$ of the diagnosed employees had sufficient knowledge and ergonomic awareness and, therefore, there was no need to provide them with additional information on this subject.

\section{Conclusions}

This research presents part of the results of work carried out as part of a commercial project aimed at improving technical and psychosocial conditions in production and service companies.

A detailed analysis of the results obtained during the conducted research allows the following conclusions to be drawn:

1. Most employees have a low level of ergonomic awareness.

2. Employees disregard difficult working conditions by performing their activities in a routine and non-ergonomic manner.

3. Employees who have knowledge about the correct posture during the performance of activities, have problems with its practical application.

4. Employers do not organise dedicated employee ergonomics training for their employees. Over $65 \%$ of employees declared that they did not participate in such trainings, and about $13 \%$ did not know if they participated.

5. Most workstations have deficiencies in the principles of ergonomic workstation design.

6. Most employees would like to gain or expand knowledge about work ergonomics.

The ergonomic condition of the work system is improving, but it is still not satisfactory. This state of affairs not only results from the low ergonomic awareness of employees, but also from the approach to the problem on the part of employers and the low effectiveness of labour protection institutions in enforcing ergonomic standards.

Based on the results obtained, it can be postulated that during periodic OSH training, not only should one present what the correct position at work should look like, or how the workstation should be properly organised, but situations and activities typical of the workplaces of trainees should also be taught. 


\section{Acknowledgements}

This paper was financed from the resources of the Silesian University of Technology, project no. BK-235/ROZ-1/2020 (13/010/BK_20/0042).

\section{References}

1. $3 D$ Static Strength Prediction Program TM, Version 7.0.2. (2018). User Manual, Michigan.

2. Bartuzi, P., and Kamińska, J. (2010). Obciążenie i dolegliwości układu mięśniowoszkieletowego a poziom wiedzy pracowników o ergonomii stanowiska komputerowego [Musculoskeletalload and disorders and workers' knowledgeabout the ergonomics of a computerworkstand]. Bezpieczeństwo Pracy, 2, pp. 21-23.

3. Berkowska, A., Drzewiecka, M., and Mrugalska, B. (2014). Świadomość pracodawców o istocie bezpieczeństwa pracy a poziom wypadków przy pracy $\mathrm{w}$ małych i średnich przedsiębiorstwach [Impact of employer'sawarenessabout essence of safetyatwork on the number of accidentsatwork in small and medium enterprises]. Zeszyty Naukowe Politechniki Śląkiej. Seria: Organizacja i Zarządzanie, 71, pp. 21-31. Available from http://stat.gov.pl/obszary-tematyczne/rynek-pracy/warunki-pracy-wypadki-przy-pracy/.

4. Deros, B.M.D., Daruis, D.D.I., and Basir, I.M. (2015). A Study on Ergonomic Awareness among Workers Performing Manual Material Handling Activities. Procedia - Social and Behavioral Sciences, 195, pp. 1666-1673.

5. Encyklopedia Popularna PWN (2010). Warszawa: PWN.

6. Gembalska-Kwiecień, A., and Żurakowski, Z. (2015). Potrzeba szkoleń z zakresu bezpieczeństwa i higieny pracy $\mathrm{w}$ przedsiębiorstwie $\mathrm{w}$ ocenie pracowników [Need for training the scope of health and safety in enterprises in the assessment of workers]. Zeszyty Naukowe. Seria: Organizacja i Zarzadzanie, 77, pp. 85-91.

7. Górska, E. (2015). Ergonomia: projektowanie, diagnoza, eksperymenty [Ergonomics: design, diagnosis, experiments]. Warszawa: Oficyna Wydawnicza Politechniki Warszawskiej Press.

8. Jasiak, A.E. (2012). Ergonomic awareness and its shaping. The Matopolska School of Economics in Tarnów Research Papers Collection, 36(4), pp. 111-128.

9. Kamińska, J., and Tokarski, T. (2012). Knowledge and usage of rules of ergonomics at computer workstations. Bezpieczeństwo Pracy - Nauka i Praktyka, 2, pp. 24-26. 
10. Kishore, P., Madhwani, K.P., and Nag, P.K. (2017). Effective Office Ergonomics Awareness: Experiences from Global Corporates. Indian Journal of Occupational and Environmental Medicine, 21(2), pp. 77-83.

11. Kuboszek, A. et al. (2018). Ergonomic diagnosis of a computer workstation. Proceedings of XV International Conference Multidisciplinary Aspects of Production Engineering, 2018-05-08 Sep 05-08. Zawiercie: PANOVA Press, pp. 437-468.

12. Modi, Y.S., Kuswaha, M.R., and Dave, S.P. (2013). Awareness of Ergonomic guidelines regarding laparoscopic surgeries, its practice among surgeons and comfort level during and after surgery. Gujarat Medical Journal, 68, pp. 31-34.

13. Najmiec, A., Kamińska, J., Bartuzi, P. et al. (2014). Indywidualne i organizacyjne sposoby przeciwdziałania wypadkom i wytyczne dotyczące ograniczania obciążenia układu mięśniowo-szkieletowego $\mathrm{w}$ budownictwie [Individual and organizationalways of preventingaccidents and guidelines for limiting the load on the musculoskeletal system in the constructionindustry]. Warsaw: CIO PIB. Available from http://www.zus.pl/ documents/10182/167529/Indywidualne_i_organizacyjne_sposoby_i_wytyczne_dot_ogr _obciazenia_ukl_miesn_szkiel_w_budownictwie.pdf/7a40eb82-0c10-4d0e-8427-fa2667a 277 af.

14. Okafor, U.C. et al. (2019). Occupational Hazards: Awareness and Level of Precautions Among Physiotherapists in Selected Health Institutions in Lagos, Nigeria. Proceedings of the 20th Congress of the International Ergonomics Association (Iea 2018). Vol. 1: Healthcare Ergonomics; 2018 Aug 26-30; Florence. Book Series: Advances in Intelligent Systems and Computing; 818 Press, pp. 600-608.

15. Olabode, S.O., and Adesanya, A.R. (2017). Ergonomics Awareness and Employee Performance: An Exploratory Study SegunOluwaseun. Economic and Environmental Studies, 17(4), pp. 813-829.

16. Pandve, H.T. (2016). Awareness about Ergonomics: Need to Create and Improve. Journal of Ergonomics, 6(1).

17. Pawlak, H., Buczaj, A., Pecyna, A., and Konowałek, M. (2016). Świadomość ergonomiczna pracowników biurowych i ich pracodawców [Ergonomicawareness of the officeworkers and theiremployers]. Zeszyty Naukowe Małopolskiej Wyższej Szkoty Ekonomicznej w Tarnowie, 31(3), pp. 141-148.

18. Pawlak, H., Maksym, P., and Pecyna, A. (2014). Analysis of awareness concerning the occupational health and safety of food sector employees. Inżynieria Rolnicza, 3(151), pp. 29-137.

19. Pual, A. (2012). A pilot study on awareness of ergonomics and prevalence of musculoskeletal injuries among Nursing professionals. International Journal of Nursing Education, 4(1), pp. 1-4.

20. Romankow, J. (2015). Wyniki badań profilaktycznych pracowników biurowych ograniczenia negatywnych skutków pracy operatorów monitorów ekranowych w okresie 
ostatnich 20 lat [Results of preventiveexaminations of officeworkers - reduction of negativeeffects of visual display unit operatorsduringlast 20 years]. Hygeia Public Health, 50(1), pp. 215-218.

21. Sirajudeen, M.S., Pillai, P.S., and Vali, G.M.Y. (2013). Assessment of Knowledge of Ergonomics among Information Technology Professionals in India. International Journal of Health and Rehabilitation Sciences, 2, pp. 192-197.

22. Sneller, T.N., Choi, S.D., and Ahn, K. (2018). Awareness and perceptions of ergonomic programs between workers and managers surveyed in the construction industry. Journal of Prevention Assessment \& Rehabilitation, 61(1), pp. 41-54.

23. Tariq, F.J., Zain, I.S., and Muneeb Ur, R.H. (2019). A cross-sectional study to assess the awareness and adherence to the guidelines of ergonomics in minimally invasive surgeries performed by residents and surgeons at a tertiary care hospital in Lahore. Indo American Journal of Pharmaceutical Sciences, 6(2), pp. 3771-3779.

24. Wypadki przy pracy w 2017 r. (2018). Statistics Poland, Statistical Office in Gdańsk. Warsaw. Available from: https://stat.gov.pl/en/topics/labour-market/working-conditionsaccidents-at-work/accidents-at-work-in-2017,3,11.html.

25. Żabińska, I., and Kuboszek, A. (2018). Ergonomic diagnosis of concrete mixer workplace. Case study. Proceedings of XV International Conference Multidisciplinary Aspects of Production Engineering; 2018 Sep 05-08; Zawiercie: PANOVA Press, pp. 751-758. 